University of Nebraska - Lincoln

DigitalCommons@University of Nebraska - Lincoln

Faculty Papers and Publications in Animal

Science

Animal Science Department

2008

\title{
Board-Invited Review: Use of Distillers By-Products in the Beef Cattle Feeding Industry
}

Terry J. Klopfenstein

University of Nebraska-Lincoln, tklopfenstein1@unl.edu

Galen E. Erickson

University of Nebraska-Lincoln, gerickson4@unl.edu

Virgil R. Bremer

University of Nebraska-Lincoln, vbremer2@unl.edu

Follow this and additional works at: https://digitalcommons.unl.edu/animalscifacpub

Part of the Animal Sciences Commons

Klopfenstein, Terry J.; Erickson, Galen E.; and Bremer, Virgil R., "Board-Invited Review: Use of Distillers ByProducts in the Beef Cattle Feeding Industry" (2008). Faculty Papers and Publications in Animal Science. 478.

https://digitalcommons.unl.edu/animalscifacpub/478

This Article is brought to you for free and open access by the Animal Science Department at DigitalCommons@University of Nebraska - Lincoln. It has been accepted for inclusion in Faculty Papers and Publications in Animal Science by an authorized administrator of DigitalCommons@University of Nebraska - Lincoln. 


\title{
BOARD-INVITED REVIEW: Use of distillers by-products in the beef cattle feeding industry ${ }^{1}$
}

\author{
T. J. Klopfenstein, ${ }^{2}$ G. E. Erickson, and V. R. Bremer
}

Department of Animal Science, University of Nebraska-Lincoln, 68583

\begin{abstract}
The ethanol industry is expanding rapidly. This expansion in production of renewable energy also increases production of by-products. These byproducts, primarily distillers grains plus solubles (DGS), are utilized very efficiently by ruminants. When the starch in corn is fermented to produce ethanol, the remaining nutrients (protein, fat, fiber) are concentrated about 3 -fold. Whereas DGS is an excellent protein source for ruminants, the large supply and the price relative to corn make DGS an attractive energy source as well. This is especially important with reduced availability and higher price of corn because of demand by the ethanol industry. A meta-analysis of 9 experiments, where various levels of wet DGS were fed to feedlot cattle, shows that wet DGS produced higher ADG and G:F compared with cattle fed corn-based diets
\end{abstract}

without DGS. A similar analysis with dry DGS showed similar type of responses but with less apparent feeding value for dry DGS compared with wet DGS. Metabolism studies suggest the fat in DGS may be partially protected from ruminal degradation leading to greater proportion of unsaturated fatty acids at the duodenum and greater total tract fat digestibility. Both the fat and the undegradable protein in DGS appear to explain some but not all of the greater feeding value of DGS compared with corn. Lower quality roughages may be used in feedlot diets containing wet DGS because of the protein, moisture, and physical characteristics the DGS contains. The feeding value of DGS is greater than dryrolled corn or high moisture corn; however, the feeding value of DGS appears to be less when fed in finishing diets based on steam-flaked corn than in those based on dry-rolled or high-moisture corn.

Key words: beef cattle, by-product, distillers grain, ethanol, feedlot

(C2008 American Society of Animal Science. All rights reserved.

J. Anim. Sci. 2008. 86:1223-1231

doi:10.2527/jas.2007-0550

\section{INTRODUCTION}

Cereal grains have been fermented to produce beverage alcohol for centuries. By the late 19th century, the resulting by-product, dried distillers grains plus solubles (DDGS) was being used as a feedstuff (Henry, 1900). Morrison (1939) and Garrigus and Good (1942) refer to a liquid form of the by-product supplied to beef cattle as distillers slop. Individuals involved in the beverage distilling industry formed the Distillers Feed Research Council in 1945 to "expand the, then, meager knowledge available on the nutrient composition of distillers feeds, and to better understand how these feeds would be best used in a variety of livestock feeding systems". The Distillers Feed Research Council was

\footnotetext{
${ }^{1}$ A contribution of the University of Nebraska Agricultural Research Division, supported in part by funds provided through the Hatch Act.

${ }^{2}$ Corresponding author: tklopfenstein1@unl.edu

Received August 31, 2007.

Accepted December 15, 2007.
}

replaced in 1997 with the Distillers Grains Technology Council (Louisville, KY). Both of these organizations have held annual conferences and the proceedings contain a wealth of information about the traditional uses of DDGS.

Stock et al. (2000) described the dry milling process where grain, mainly corn, is fermented to produce ethanol. About two-thirds of corn is starch, which is the component that is fermented to ethanol in the dry milling process. The remaining nutrients are recovered in the stillage, and water is removed to produce DDGS. Therefore, protein, fat, fiber, and $\mathrm{P}$ concentrations are increased 3-fold in the DDGS compared with corn. Protein increases from about 10 to $30 \%$, fat from 4 to $12 \%$, NDF from 12 to $36 \%$, and P from 0.3 to $0.9 \%$ of DM.

Because of the increased concentration of protein in the DDGS compared with corn, the DDGS was used primarily as a protein source (Klopfenstein et al., 1978). Zein is the primary protein in corn and as a result in DDGS as well. McDonald (1954) showed that zein was about $40 \%$ degraded in the rumen. Little et al. (1968) confirmed high rumen escape values for zein. Aines et al. (1987) reviewed reports on rumen protein escape 
Table 1. Calf performance when feeding different dietary inclusions of wet distillers grains plus solubles (WDGS) for protein and energy ${ }^{1}$

\begin{tabular}{|c|c|c|c|c|c|c|c|}
\hline \multirow[b]{2}{*}{ Item } & \multicolumn{4}{|c|}{ WDGS level, ${ }^{2} \%$ of diet DM } & \multirow[b]{2}{*}{$\mathrm{SE}$} & \multicolumn{2}{|c|}{$P$-value } \\
\hline & 0 & 5.2 & 12.6 & 40.0 & & Linear & Quadratic \\
\hline DMI, kg/d & 8.42 & 8.74 & 8.44 & 7.91 & 0.13 & $<0.01$ & 0.21 \\
\hline $\mathrm{ADG}, \mathrm{kg}$ & 1.30 & 1.39 & 1.40 & 1.46 & 0.03 & $<0.01$ & 0.13 \\
\hline$G: F^{3}$ & 0.155 & 0.158 & 0.164 & 0.177 & 0.003 & $<0.01$ & 0.54 \\
\hline $\mathrm{HCW}, \mathrm{kg}$ & 324 & 333 & 336 & 342 & 3 & 0.01 & 0.15 \\
\hline Fat thickness & 1.3 & 1.4 & 1.4 & 1.4 & 0.1 & 0.21 & 0.27 \\
\hline Marbling score ${ }^{4}$ & 497 & 530 & 530 & 580 & 20 & 0.01 & 0.51 \\
\hline
\end{tabular}

${ }^{1}$ Adapted from Larson et al. (1993).

${ }^{2}$ Wet grains:thin stillage $=1.67: 1, \mathrm{DM}$ basis

${ }^{3}$ Accounts for ethanol consumption.

${ }^{4} 400=$ Slight $^{0}$ and $500=$ Small $^{0}$.

values of DDGS and found them to be variable, likely due to technique of measurement. Mean escape values for DDGS were 2.6 times soybean meal, and values for dry distillers grains without solubles (DDG) were 2.3 times soybean meal. Klopfenstein et al. (1978) used the slope ratio technique in growth studies to determine protein values relative to soybean meal using that technique. Aines et al. (1987) summarized several experiments showing 2.4 times the value of DDG protein compared with that from soybean meal, and DDGS had 1.8 times the value of soybean meal. DeHaan et al. (1982) found a value of 0.45 times soybean protein from distillers solubles (DS). One might expect that the protein in DS would be completely rumen degradable, especially when DS are produced by centrifugation that would remove most grain particles. However, much of the protein in DS is yeast cells that have been heated during distillation and concentration. Bruning and Yokoyama (1988) showed that heat denatured yeast rendering them resistant to lyses and microbial degradation. Herold (1999) showed only $20 \%$ protein degradation in the rumen of DS, which contained mostly yeast cells, from the wet milling industry. Therefore, some escape of protein in DS should be expected.

In addition to protein, NDF is concentrated in distillers grains plus solubles (DGS) compared with corn and composes most of the carbohydrate in DGS. Quicke et al. (1959) found high in vitro digestion of cellulose in corn fiber. DeHaan et al. (1983) demonstrated that corn bran (corn grain pericarp) is primarily NDF (69\%) and that the NDF has a high extent $(87 \%)$ and rate $(6.2 \%$ / h) of digestion. Sayer (2004) reported similar extents of corn bran NDF digestion (79 to 84\%) in situ in fistulated cattle fed finishing diets. Rates of digestion of NDF in these finishing diets were less (1.7 to $2.1 \% / \mathrm{h}$ ) than those reported by DeHaan et al. (1983), likely due to relatively low ruminal $\mathrm{pH}$ in the finishing diets.

During the 1990s, production of ethanol for fuel increased. In the past few years, there has been an exponential increase in fuel ethanol production, and the growth is expected to continue. The CAST (2006) projects up to 20 billion gallons of ethanol per year may be

Table 2. Cattle performance when feeding different dietary inclusions of wet distillers grains plus solubles (WDGS) to finishing yearling steers ${ }^{1}$

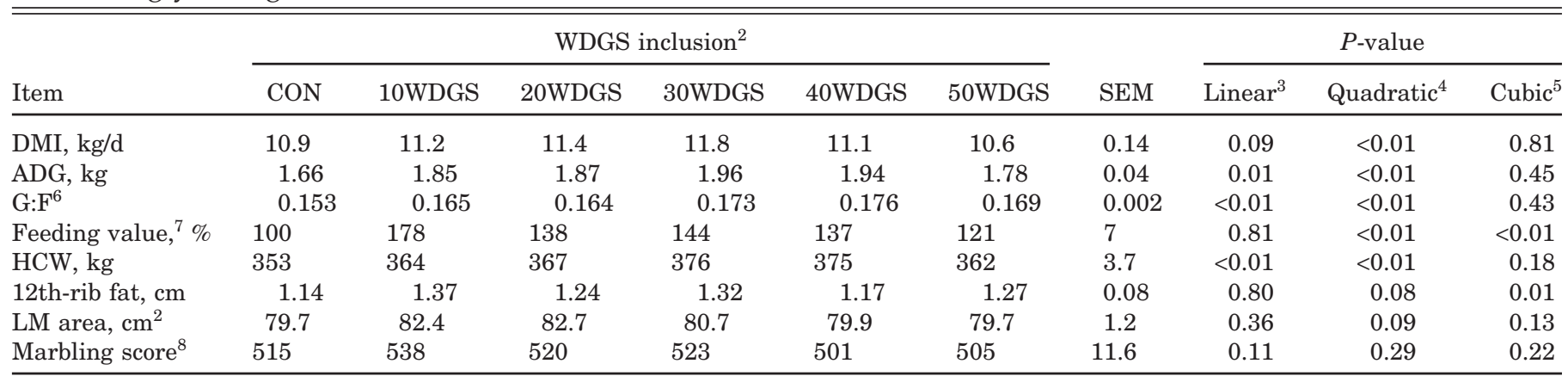

\footnotetext{
${ }^{1}$ Adapted from Vander Pol et al. (2006b). 40WDGS $=40 \%$ WDGS, and 50WDGS $=50 \%$ WDGS .

${ }^{3}$ Contrast for the linear effect of treatment.

${ }^{4}$ Contrast for the quadratic effect of treatment.

${ }^{5}$ Contrast for the cubic effect of treatment.

${ }^{6}$ Calculated as total gain over total dry matter intake.

${ }^{7}$ Calculated from G:F relative to control, divided by WDGS inclusion.

${ }^{8} 400=$ Slight $^{0}, 500=$ Small $^{0}$.
}

${ }^{2}$ Dietary treatment levels (DM basis) of WDGS: CON $=0 \%$ WDGS, 10WDGS $=10 \%$ WDGS, 20 WDGS $=20 \%$ WDGS, 30WDGS $=30 \%$ WDGS, 
Table 3. Wet distillers grains plus solubles (WDGS) meta-analysis predicted values ${ }^{1}$

\begin{tabular}{|c|c|c|c|c|c|c|c|c|}
\hline \multirow[b]{2}{*}{ Item } & \multicolumn{6}{|c|}{ WDGS level, \% of diet DM } & \multicolumn{2}{|c|}{$P$-value } \\
\hline & 0 & 10 & 20 & 30 & 40 & 50 & Linear & Quadratic \\
\hline DMI, kg/d & 10.12 & 10.31 & 10.33 & 10.20 & 9.90 & 9.44 & 0.01 & 0.01 \\
\hline $\mathrm{ADG}, \mathrm{kg}$ & 1.57 & 1.68 & 1.74 & 1.76 & 1.73 & 1.66 & $<0.01$ & $<0.01$ \\
\hline G:F & 0.155 & 0.162 & 0.168 & 0.172 & 0.174 & 0.175 & $<0.01$ & 0.09 \\
\hline Feeding value, ${ }^{2} \%$ & 100 & 145 & 142 & 137 & 131 & 126 & & \\
\hline Fat thickness, cm & 1.24 & 1.32 & 1.37 & 1.37 & 1.32 & 1.24 & $<0.01$ & 0.04 \\
\hline Yield grade & 2.85 & 2.95 & 3.02 & 3.04 & 3.01 & 2.94 & $<0.01$ & 0.06 \\
\hline Marbling score ${ }^{3}$ & 518 & 528 & 533 & 532 & 526 & 514 & 0.05 & 0.05 \\
\hline
\end{tabular}

${ }^{1}$ Data set included treatment means from Buckner et al. (2007), Corrigan et al. (2007), Al-Suwaiegh et al. (2002), Ham et al. (1994), Larson et al. (1993), Luebbe et al. (2007), Vander Pol et al. (2006b), and Vander Pol et al. (2006a).

${ }^{2}$ Value relative to corn, calculated by difference of G:F divided by by-product inclusion.

${ }^{3} 500=$ Small $^{0}$.

produced. That would result in nearly 70 million tons of DGS. The increase in production of DGS in wet or dry form stimulated our interest in use of DGS as an energy source. Considering using a protein source as a feed energy source was a major paradigm shift.

\section{WET DISTILLERS GRAINS PLUS SOLUBLES}

Perhaps the first study designed to include DGS as an energy source was conducted by Farlin (1981). Farlin fed wet distillers grains without solubles (WDG) replacing 25,50 , and $75 \%$ of the corn in a finishing diet. Even though the perceived energy nutrient (starch) in corn had been removed, the resulting by-product (WDG) actually had more energy per kilogram of DM than the corn it replaced. Firkins et al. (1985) and Trenkle (1996, 1997) found similar results with wet distillers grains plus solubles (WDGS).

Larson et al. (1993) conducted a series of experiments designed to evaluate WDGS fed as a protein source or as an energy source. The hypothesis was that locating an ethanol plant adjacent to a feedlot would allow feeding of the product wet, eliminating the necessity of drying the by-product. The WDGS was fed at 5.2 and $12.6 \%$ of diet DM to supply MP or CP needs. The $40 \%$ level in the diet (DM basis) supplied protein and replaced corn in the diet as an energy source. At the $40 \%$ level, feed efficiency of the diet was increased 14\% compared with the corn control (Table 1). Assuming the entire increase in efficiency was due to the WDGS, the WDGS had $35 \%$ greater feeding value than corn.

Vander Pol et al. (2006b) fed 0, 10, 20, 30, 40, and $50 \%$ WDGS replacing corn. They found quadratic responses to $\mathrm{ADG}$ and $\mathrm{G}: \mathrm{F}$ and a cubic response in feeding value to WDGS level (Table 2). Feed efficiency at all levels of WDGS was greater than the corn control diet.

Nine experiments conducted in the same feedlot under relatively similar conditions were used for a metaanalysis. Levels of WDGS replacing dry-rolled corn (DRC), high-moisture corn (HMC), or a DRC and HMC combination ranged from 5.2 to $50 \%$. Most common levels were 30 or $40 \%$, and there was only 1 comparison at $50 \%$. Experiments had 10 (individually fed) to 50 steers per treatment, most above 40 steers per treatment. The 9 experiments included 34 treatment means representing 1,257 steers.

There were quadratic responses to $\mathrm{ADG}$ and $\mathrm{DMI}$ (Table 3) with ADG and DMI being maximized at about $30 \%$ WDGS. The G:F of the diet was maximized at 30 to $50 \%$ of diet, and the relationship tended to be quadratic $(P<0.09)$. Feeding values calculated from G:F values showed decreasing feeding values as level of WDGS in the diet increased. The G:F values did not decrease for the diets at the high inclusion levels, but because of accounting for inclusion level in the diet, feeding values decreased with inclusion level. Because cattle gained more rapidly when fed WDGS compared with corn, they were fatter with equal days on feed. Consistent with the quadratic increase in rib fat was a quadratic increase in quality grade. Roeber et al. (2005) and Jenschke et al. (2007) showed that feeding DDGS and WDGS had no significant impact on palatability of the meat.

\section{DRY DISTILLERS GRAINS PLUS SOLUBLES}

Drying of DG is expensive because of the cost of fuel and the capital investment in equipment. Fuel ethanol

Table 4. Effect of wet or dry distillers by-products on finishing cattle performance ${ }^{1}$

\begin{tabular}{|c|c|c|c|c|c|c|}
\hline \multirow[b]{3}{*}{ Item } & \multirow[b]{3}{*}{ Control } & \multicolumn{4}{|c|}{ Distillers by-product and ADIN level ${ }^{2}$} & \multirow[b]{3}{*}{ SEM } \\
\hline & & \multirow[b]{2}{*}{ WDB } & \multicolumn{3}{|c|}{ DDGS } & \\
\hline & & & Low & Medium & High & \\
\hline $\mathrm{ADG},{ }^{3,4} \mathrm{~kg}$ & 1.46 & 1.69 & 1.66 & 1.68 & 1.71 & 0.12 \\
\hline $\mathrm{DMI},{ }^{5,6} \mathrm{~kg} / \mathrm{d}$ & 10.99 & 10.68 & 11.48 & 11.36 & 11.73 & 0.55 \\
\hline $\mathrm{G}: \mathrm{F}^{3,4,6}$ & 0.133 & 0.158 & 0.144 & 0.148 & 0.145 & 0.004 \\
\hline \multicolumn{7}{|c|}{$\begin{array}{l}{ }^{1} \text { Adapted from Ham et al. (1994). } \\
2 \text { DDGS = dried distillers grains plus solubles and WDB }= \\
\text { distillers by-products. } \\
{ }^{3} \text { Control vs. WDB }(P<0.05) \text {. } \\
{ }^{4} \text { Control vs. the average of the DDGS composites }(P<0.05) \text {. } \\
{ }^{5} \text { Conrol vs. the average of the DDGS composites }(P<0.10) \text {. } \\
{ }^{6} \text { WDB vs. the average of the DDGS composites }(P<0.05) \text {. }\end{array}$} \\
\hline
\end{tabular}


Table 5. Cattle performance when feeding increasing levels of dried distillers grains plus solubles (DDGS) to finishing steers ${ }^{1,2}$

\begin{tabular}{|c|c|c|c|c|c|c|c|c|}
\hline \multirow[b]{2}{*}{ Item } & \multirow[b]{2}{*}{ 0DDGS } & \multirow[b]{2}{*}{ 10DDGS } & \multirow[b]{2}{*}{ 20DDGS } & \multirow[b]{2}{*}{ 30DDGS } & \multirow[b]{2}{*}{ 40DDGS } & \multirow[b]{2}{*}{ SEM } & \multicolumn{2}{|c|}{$P$-value } \\
\hline & & & & & & & Linear $^{3}$ & Quadratic $^{4}$ \\
\hline DMI, kg/d & 9.25 & 9.47 & 9.52 & 9.71 & 9.47 & 0.17 & 0.23 & 0.30 \\
\hline $\mathrm{ADG}, \mathrm{kg}$ & 1.50 & 1.61 & 1.68 & 1.62 & 1.59 & 0.05 & 0.26 & 0.05 \\
\hline $\mathrm{G}: \mathrm{F}^{5}$ & 0.162 & 0.171 & 0.177 & 0.168 & 0.168 & 0.005 & 0.61 & 0.14 \\
\hline Feeding value $^{6}$ & 100 & 156 & 146 & 112 & 109 & & & \\
\hline $\mathrm{HCW}, \mathrm{kg}$ & 351 & 362 & 370 & 364 & 359 & 5.62 & 0.32 & 0.04 \\
\hline 12th-rib fat, cm & 1.42 & 1.37 & 1.50 & 1.40 & 1.47 & 0.08 & 0.48 & 0.99 \\
\hline $\mathrm{LM}$ area, $\mathrm{cm}^{2}$ & 80.0 & 80.6 & 82.6 & 81.3 & 81.3 & 1.29 & 0.42 & 0.37 \\
\hline Marbling score ${ }^{7}$ & 533 & 537 & 559 & 527 & 525 & 12.7 & 0.50 & 0.18 \\
\hline $\begin{array}{l}{ }^{1} \text { Adapted from } \\
{ }^{2} \text { 0DDGS = } 0 \% \mathrm{D} \\
40 \% \text { DDGS. } \\
{ }^{3} \text { Contrast for t } \\
{ }^{4} \text { Contrast for tl } \\
{ }^{5} \text { Calculated as } \\
{ }^{6} \text { Value relative } \\
{ }^{7} 400=\text { Slight }{ }^{0},\end{array}$ & $\begin{array}{l}\text { DGS, 10D } \\
\text { he linear } \\
\text { he quadra } \\
\text { total gain } \\
\text { to corn, c } \\
500=\mathrm{Sm}\end{array}$ & $\begin{array}{l}\text { fect of trea } \\
\text { c effect of } \\
\text { ver total } d \\
\text { lculated by } \\
11^{0} \text {. }\end{array}$ & $\begin{array}{l}\text { DGS, 20D } \\
\text { ment. } \\
\text { reatment. } \\
\text { ry matter i } \\
\text { difference }\end{array}$ & $\begin{array}{l}\text { ake. } \\
\text { G:F div }\end{array}$ & $\mathrm{GS}, 30$ & $=$ & DGS, & 40DDGS $=$ \\
\hline
\end{tabular}

is an energy source designed to replace fossil fuel (CAST, 2006). Use of fossil fuel for drying is counterproductive. Although many feedlot cattle are located in proximity to dry milling plants, many are too far from plants to allow transportation of WDGS to feedlots. In those cases, it may be logical and economical to dry DGS to facilitate transportation.

Ham et al. (1994) compared feeding values of DDGS to WDGS in feedlot diets. The DGS were included at $40 \%$ of diet DM replacing corn. The WDGS were produced in a separate plant from the DDGS. The DDGS were from 11 sources and were combined into composites based on ADIN content. Cattle fed both WDGS and DDGS were more efficient than the control, corn-fed cattle (Table 4). Cattle fed WDGS were more efficient than cattle fed DDGS. Amount of ADIN did not affect G:F. The WDGS contained $47 \%$ greater feeding value than corn, and DDGS contained $24 \%$ greater value.

Buckner et al. (2007) conducted a feedlot study comparing 10,20,30, and $40 \%$ levels of DDGS to a corn control. A trend for a quadratic response was observed for G:F (Table 5). The quadratic response in G:F was similar to that found for WDGS by Vander Pol et al. (2006b), but the G:F response was somewhat less and optimal inclusion was $20 \%$ of diet DM. These data were combined with 4 other experiments in a meta-analysis. The meta-analysis showed a quadratic response in ADG and a cubic response in G:F as level of DDGS in the diet increased from 0 to $40 \%$ (Table 6). Maximum ADG was between 20 to $30 \%$ DDGS and maximum G:F was between 10 to $20 \%$ DDGS. Compared with the metaanalysis for WDGS, the inclusion levels for maximum response were lower for DDGS for both $\mathrm{ADG}$ and G:F. In addition, the feeding value declined from the $20 \%$ inclusion level (123\%) to the $40 \%$ inclusion level (100\%). In contrast, the feeding value of WDGS at the $20 \%$ inclusion was 142 and declined only to $131 \%$ at the $40 \%$ inclusion level. There appears to be a biological interaction between DDGS and WDGS in feeding values at different levels of inclusion. At $20 \%$ level of inclusion, the 2 types of DG differed in feeding values by 19 percentage units but differed by about 31 percentage units at $40 \%$ of dietary inclusion. This is an observation and not an interaction in a strict statistical sense. The explanation for this interaction and the explanation for a drying effect are not apparent.

Protein, fat, and $\mathrm{P}$ are increased approximately 3fold from corn to DGS. When fed as an energy source (above 15 to $20 \%$ of diet DM), protein and $\mathrm{P}$ are overfed. In addition, sulfuric acid is used for $\mathrm{pH}$ control and cleaning resulting in S levels of 0.6 to $1.0 \%$ or greater in DGS. Excess protein used for energy is deaminated and subsequent urea is excreted. Huntington and Archibeque (2000) suggest 1 to $4 \mathrm{~mol}$ of ATP is needed to synthesize $1 \mathrm{~mol}$ of urea and the change in ME use is difficult to detect (i.e., very small). There is no apparent evidence that high levels of $\mathrm{P}$ are detrimental to feedlot cattle as long as sufficient Ca is supplemented. Elevated levels of dietary $\mathrm{S}$ are problematic (Lonergan et al., 2001). Although $S$ is required by ruminal microorganisms, high levels may cause polioencephalomalacia, reduce $\mathrm{DMI}$ and $\mathrm{ADG}$, and reduce liver $\mathrm{Cu}$ stores. Declining DMI at DGS inclusion levels above 30 to $40 \%$ may be partially explained by S, lipid, or both in the DGS.

\section{METABOLISM AND DIGESTION OF DISTILLERS GRAINS}

It is a paradox that both WDGS and DDGS appear to have greater feeding values than corn and yet are less digestible because of the NDF in the DGS. Lodge et al. (1997b) attempted to determine the reason for this apparent paradox. They developed a composite DG with composition as similar as possible to the DDGS. Ingredients in the composite were wet corn gluten feed (corn bran and steep liquor), corn gluten meal, and 
Table 6. Dried distillers grains plus solubles (DDGS) meta-analysis predicted values ${ }^{1}$

\begin{tabular}{|c|c|c|c|c|c|c|c|c|}
\hline \multirow[b]{2}{*}{ Item } & \multicolumn{5}{|c|}{ DDGS level, \% of diet DM } & \multicolumn{3}{|c|}{$P$-value } \\
\hline & 0 & 10 & 20 & 30 & 40 & Linear & Quadratic & Cubic \\
\hline DMI, kg/d & 10.17 & 10.40 & 10.53 & 10.56 & 10.49 & 0.01 & 0.08 & 0.68 \\
\hline $\mathrm{ADG}, \mathrm{kg}$ & 1.56 & 1.65 & 1.69 & 1.70 & 1.66 & $<0.01$ & $<0.01$ & 0.54 \\
\hline $\mathrm{G}: \mathrm{F}$ & 0.152 & 0.160 & 0.159 & 0.155 & 0.152 & 0.07 & 0.02 & $<0.01$ \\
\hline Feeding value, ${ }^{2} \%$ & 100 & 153 & 123 & 107 & 100 & & & \\
\hline Yield grade & 2.87 & 2.91 & 2.94 & 2.98 & 3.01 & 0.04 & 0.51 & 0.90 \\
\hline Marbling score ${ }^{3}$ & 540 & 535 & 529 & 524 & 518 & 0.07 & 0.13 & 0.79 \\
\hline
\end{tabular}

${ }^{1}$ Data set included treatment mean observations from Buckner et al. (2007), Bremer et al. (2005), Benson et al. (2005), Ham et al. (1994), and May et al. (2007a).

${ }^{2}$ Value relative to corn, calculated by difference of $\mathrm{G}: \mathrm{F}$, divided by by-product inclusion.

${ }^{3} 500=$ Small $^{0}$.

tallow. The feeding value of the composite when fed at $40 \%$ of diet DM was $124 \%$ of the corn it replaced (Table 7). This feeding value is comparable with the metaanalysis of WDGS described previously. When either corn gluten meal or tallow were removed, G:F decreased numerically a similar amount, indicating the escape protein in the corn gluten meal and the tallow were equally responsible for the high feeding value of the composite. It is unlikely, but possible, that the corn gluten meal met a metabolizable protein deficiency. The response is more likely from the greater energetic efficiency of undegradable intake protein compared with degraded protein or carbohydrates. The undegradable intake protein does not undergo any fermentation losses. The higher energy value of lipid for ruminants (Zinn, 1989) certainly explains the response to tallow. Larson et al. (1993) estimated that the undegraded protein and fat in WDGS would increase the feeding value by about $20 \%$ compared with corn. This is less than the value of $30 \%$ in the meta-analysis and does not account for lower digestibility of NDF in WDGS compared with starch in corn. Therefore, the paradox remains unexplained.

Metabolism of the lipid in DG is important from an energetic as well as a meat composition standpoint. Vander Pol et al. (2007) conducted a feedlot study and a metabolism study to elucidate the role of lipid in the DGS. Five percent corn oil added to the control, cornbased diet reduced G:F by $10 \%$. Conversely, adding a similar amount of lipid from WDGS increased G:F by $8 \%$. Fat added as corn oil was $70 \%$ digested, whereas fat added in WDGS was $81 \%$ digested. Fatty acid profiles were measured in duodenal contents (Table 8). Unsaturated fatty acids were higher (30.9\% of total fat) in duodenal contents of steers fed WDGS than steers fed similar amounts of corn oil (10.8\% of total fat). This suggests that some of the oil in WDGS was protected from rumen hydrolysis/hydrogenation. Plascencia et al. (2003) showed that fat digestion is decreased with hydrogenation. Therefore, these data (Vander Pol et al., 2007) are consistent by showing reduced hydrogenation and increased digestibility of the lipid in WDGS compared with free corn oil. Metabolism data are also consistent with the feeding study in which the lipid resulted in a positive animal response in WDGS, whereas oil gave a negative animal response. This negative influence could be due to influence on rumen fermentation or fat digestion. Plascencia et al. (2003) reported that intestinal fatty acid digestion decreased with level of total fatty acid intake, regardless of saturation. This response might suggest that the declining feed value of DGS as inclusion levels in the diet increase are at least partially due to declining fatty acid digestion. The negative effect of fat on rumen fermentation has been demonstrated (Zinn et al., 2000) and may be additive to the decreased digestion of fat.

\section{ROUGHAGE LEVELS AND SOURCES}

Starch has been removed in the production of ethanol so when DGS is included in the diet, especially at levels above $20 \%$ of DM, the amount of starch in the diet is

Table 7. Effect of wet grains composite on finishing steer performance ${ }^{1}$

\begin{tabular}{lllllll}
\hline \hline & & \multicolumn{5}{c}{ Treatment $^{2}$} \\
\cline { 3 - 6 } Item & DRC & WCGF & COMP2 & -FAT & -CGM & SEM \\
\hline DMI, kg/d & $9.75^{\mathrm{a}}$ & $9.48^{\mathrm{ab}}$ & $9.05^{\mathrm{b}}$ & $9.08^{\mathrm{b}}$ & $9.43^{\mathrm{ab}}$ & 0.54 \\
$\mathrm{ADG}, \mathrm{kg}$ & 1.33 & 1.30 & 1.35 & 1.32 & 1.33 & 0.13 \\
G:F & $0.136^{\mathrm{a}}$ & $0.136^{\mathrm{a}}$ & $0.149^{\mathrm{b}}$ & $0.146^{\mathrm{ab}}$ & $0.146^{\mathrm{ab}}$ & 0.023 \\
\hline
\end{tabular}

${ }^{\mathrm{a}, \mathrm{b}}$ Means within a row with unlike superscripts differ $(P<0.10)$.

${ }^{1}$ Adapted from Lodge et al. (1997b).

${ }^{2} \mathrm{DRC}=$ dry-rolled corn; WCGF = wet corn gluten feed; COMP2 = wet corn gluten feed, corn gluten meal, and tallow; $-\mathrm{FAT}=$ composite minus tallow; $-\mathrm{CGM}=$ composite minus corn gluten meal . 
Table 8. Fatty acid profiles of duodenal fat content of steers fed wet distillers grains plus solubles (WDGS) or supplemental corn oil ${ }^{1}$

\begin{tabular}{lccc}
\hline \hline & \multicolumn{3}{c}{ Treatment $^{3}$} \\
\cline { 2 - 4 } Item $^{2}$ & WDGS & CON & CON + OIL \\
\hline 16 and 18 C unsaturated & 30.9 & 20.1 & 18.4 \\
14 to 18 C saturated & 64.0 & 71.7 & 75.3 \\
Other & 5.1 & 8.2 & 6.3 \\
Unsaturated:saturated & 0.48 & 0.28 & 0.24 \\
\hline
\end{tabular}

${ }^{1}$ Adapted from Vander Pol et al. (2007).

${ }^{2}$ Expressed as a proportion of the fat reaching the duodenum.

${ }^{3} \mathrm{CON}=$ average of control diet and composite diet, and CON + $\mathrm{OIL}=$ average of control + corn oil diet and composite + corn oil diet.

decreased, whereas fiber, protein, and fat are increased. This suggests that subacute acidosis should be reduced and roughage (forage) content of the diet could be reduced when DGS is included in diets above $20 \%$ of DM. Acidosis control (Krehbiel et al., 1995) and reduced roughage needs (Farran et al., 2006) have been demonstrated with wet corn gluten feed, which has a similar amount of corn fiber to that in DGS. In addition to supplying NDF and reducing starch in the diet, WDGS adds moisture and protein to the diet. The moisture and physical characteristics (stickiness) aid markedly in palatability and reduce separation and sorting of less palatable ingredients. The protein in WDGS reduces the need for (value of) protein in the roughage. Therefore, less expensive, lower digestibility forages may be acceptable in diets with reasonably high levels of WDGS.

A feedlot study tested the response to roughage level and source in diets containing 30\% WDGS (Benton et al., 2007). Alfalfa was used as the "gold standard" roughage and was fed at 4 and $8 \%$ of diet DM. Cornstalks were evaluated at amounts of NDF similar to the alfalfa ( 3 and $6 \%$ of diet DM). Corn silage was included as the third roughage source theorizing that corn silage could be harvested and stored less expensively as silage compared with harvest of corn and cornstalks separately, yet provide both components. The silage was also included on an equal NDF basis at 6 and $12 \%$ of diet DM. An all-concentrate diet (no roughage) was included as a control. There was a 1 to $1.5 \mathrm{~kg} /$ $\mathrm{d}$ increase in DMI due to roughage inclusion, whereas ADG increased 0.09 to $0.22 \mathrm{~kg} / \mathrm{d}$ (Table 9). These in- creases in DMI and ADG are typical of those observed in studies evaluating roughage levels in diets without WDGS (Shain et al., 1999). These data suggest WDGS did not supply roughage even though it supplied NDF. However, cornstalks were as effective as alfalfa and corn silage in diets containing WDGS in providing roughage in terms of response in DMI, ADG, and G:F. This is contrary to Shain et al. (1999) where wheat straw fed on an equal NDF basis to alfalfa in dry-rolled corn diets was not as efficiently utilized as alfalfa. This suggests the moisture and protein in WDGS do in fact supply characteristics to the diet that allow utilization of low-quality roughages.

\section{GRAIN PROCESSING}

All of the data discussed have evaluated DGS in feedlot diets based on DRC or HMC. Vasconcelos and Galyean (2007) put together a very insightful survey of feedlot nutritionists. They reported that $65.5 \%$ of nutritionists surveyed stated that steam flaking was the most common method of corn processing. This does not mean that $65 \%$ of the corn fed to feedlot cattle is steam-flaked corn (SFC), only that $65 \%$ of the nutritionists in their survey responded accordingly. Their publication was not designed to quantify the amount of SFC fed in feedlots. The total amount of SFC may be greater than or less than $65 \%$. Regardless, SFC represents a large proportion of grain fed to feedlot cattle, especially in the Southern High Plains. Ethanol plants have been and are being built in corn belt states where feeding DRC and HMC are more common.

Vander Pol et al. (2006a) fed DRC, SFC, and HMC with $30 \%$ WDGS to finishing cattle. From the metaanalysis, this $30 \%$ inclusion level with DRC or HMC would be optimal for rate and efficiency of gain. Although not statistically significant, the G:F for HMC was $4 \%$ greater than that for DRC (Table 10). With each corn at $61 \%$ of diet DM, the HMC calculates to have $6.5 \%$ greater feeding value than DRC, which is consistent with data when these corns are fed with wet corn gluten feed (Macken et al., 2006). Macken et al. (2006) suggested that SFC has 10 to $15 \%$ greater feeding value than DRC, with the greater values observed when fed with wet corn gluten feed. However, Vander Pol et al. (2006a) found similar G:F for SFC- and DRC-

Table 9. Finishing performance of cattle fed diets containing wet distillers grains plus solubles with 3 types of roughage at low or normal NDF levels ${ }^{1,2}$

\begin{tabular}{lcccccccl}
\hline \hline Item & CON & LALF & LCSIL & LCSTK & NALF & NCSIL & NCSTK & SE \\
\hline DMI, kg/d & $10.1^{\mathrm{a}}$ & $11.1^{\mathrm{b}}$ & $11.0^{\mathrm{b}}$ & $11.3^{\mathrm{bc}}$ & $11.7^{\mathrm{c}}$ & $11.5^{\mathrm{c}}$ & $11.6^{\mathrm{c}}$ & 0.2 \\
ADG, kg & $1.96^{\mathrm{a}}$ & $2.06^{\mathrm{ab}}$ & $2.05^{\mathrm{a}}$ & $2.17^{\mathrm{c}}$ & $2.16^{\mathrm{bc}}$ & $2.15^{\mathrm{bc}}$ & $2.18^{\mathrm{c}}$ & 0.05 \\
G:F & 0.195 & 0.186 & 0.186 & 0.192 & 0.185 & 0.188 & 0.188 & 0.003 \\
\hline
\end{tabular}

${ }^{\mathrm{a}-\mathrm{c}}$ Means within a row with unlike superscripts differ $(P<0.05)$.

${ }^{1}$ Adapted from Benton et al. (2007).

${ }^{2} \mathrm{CON}=$ Control, LALF $=$ low alfalfa hay $(4 \%)$, LCSIL $=$ low corn silage $(6 \%)$, LCSTK $=$ low corn stalks $(3 \%), \mathrm{NALF}=$ normal alfalfa hay $(8 \%), \mathrm{NCSIL}=$ normal corn silage $(12 \%)$, and NCSTK $=$ normal corn stalks $(6 \%)$. 


\section{Gain:Feed}

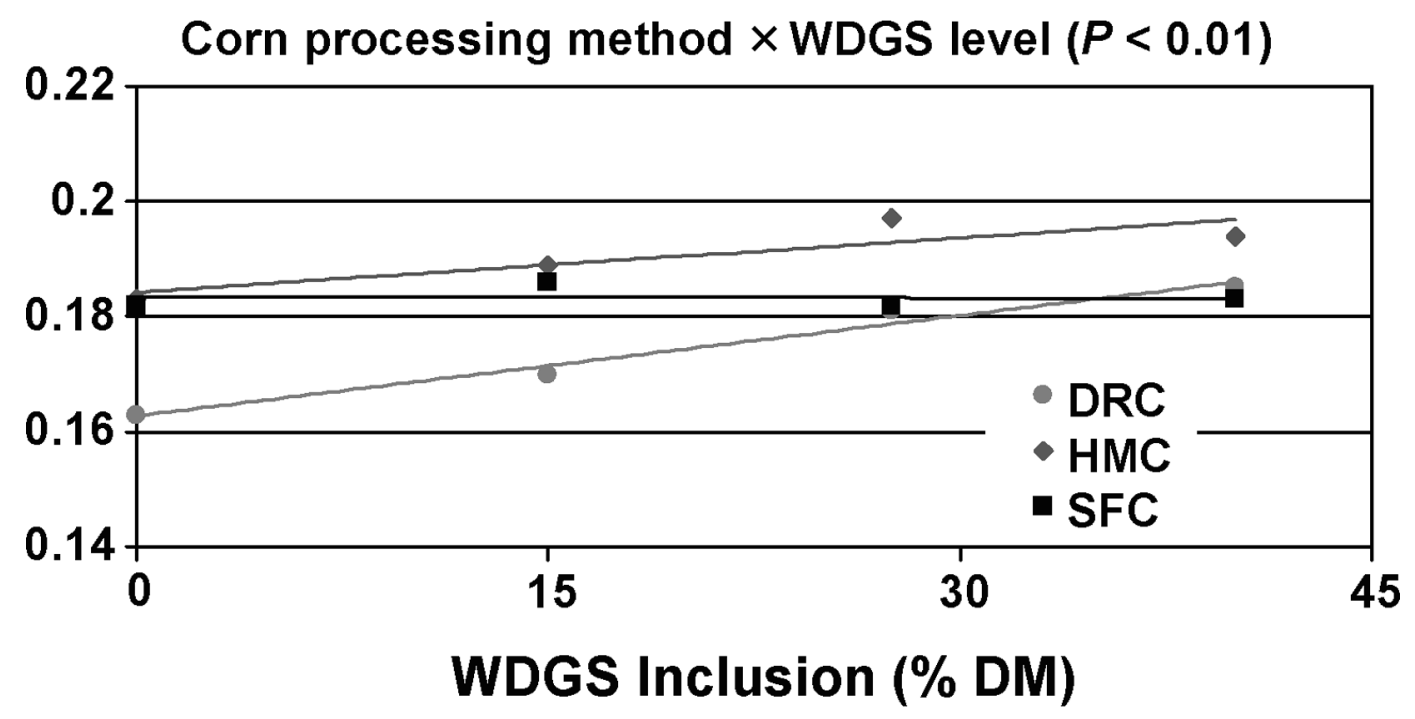

\section{Linear effect of WDGS level in DRC $(P<0.01)$ Linear effect of WDGS level in HMC $(P<0.05)$}

Figure 1. Efficiency of gain of finishing steers fed differing levels of WDGS (wet distillers grains plus solubles) with dry rolled corn (DRC), high moisture corn (HMC), or steam flaked corn (SFC). Adapted from Corrigan et al. (2007).

fed cattle when $30 \%$ WDGS was included in the diet, and $\mathrm{ADG}$ was significantly decreased for cattle fed SFC compared with DRC or HMC. Drouillard et al. (2005) also obtained less response to the combination of WDGS and SFC than expected and suggested the optimal level of WDGS was less than the $30 \%$ level used by Vander Pol et al. (2006a).

Corrigan et al. (2007) evaluated the interaction between WDGS inclusion and grain processing method. The WDGS was fed at $0,15,27.5$, and $40 \%$ of DM in

Table 10. Performance and carcass characteristics of steers fed $30 \%$ wet distillers grains plus solubles and corn from 3 processing methods ${ }^{1}$

\begin{tabular}{|c|c|c|c|c|c|}
\hline \multirow[b]{2}{*}{ Item } & \multicolumn{3}{|c|}{ Treatment $^{2}$} & \multirow[b]{2}{*}{ SEM } & \multirow[b]{2}{*}{$F$-test } \\
\hline & $\mathrm{SFC}$ & $\mathrm{HMC}$ & $\mathrm{DRC}$ & & \\
\hline DMI, kg/d & $9.28^{\mathrm{b}}$ & $9.53^{\mathrm{ab}}$ & $10.28^{\mathrm{a}}$ & 0.10 & $<0.01$ \\
\hline $\mathrm{ADG},{ }^{3} \mathrm{~kg}$ & $1.63^{\mathrm{c}}$ & $1.77^{\mathrm{ab}}$ & $1.84^{\mathrm{a}}$ & 0.03 & $<0.01$ \\
\hline $\mathrm{G}: \mathrm{F}^{3,4}$ & $0.176^{\mathrm{b}}$ & $0.185^{\mathrm{a}}$ & $0.179^{\mathrm{ab}}$ & 0.002 & $<0.01$ \\
\hline Fecal starch & $4.2^{\mathrm{c}}$ & $8.7^{\mathrm{b}}$ & $12.0^{\mathrm{ab}}$ & 1.3 & $<0.01$ \\
\hline $\mathrm{HCW}, \mathrm{kg}$ & $373^{\mathrm{c}}$ & $387^{a b}$ & $395^{\mathrm{a}}$ & 3 & $<0.01$ \\
\hline 12th-rib fat, $\mathrm{cm}$ & $1.30^{\mathrm{c}}$ & $1.47^{\mathrm{ab}}$ & $1.57^{\mathrm{a}}$ & 0.05 & $<0.01$ \\
\hline $\mathrm{LM}$ area, $\mathrm{cm}^{2}$ & 81.3 & 85.1 & 83.9 & 1.3 & 0.16 \\
\hline Marbling score ${ }^{5}$ & $496^{\mathrm{b}}$ & $544^{\mathrm{a}}$ & $540^{\mathrm{a}}$ & 10 & $<0.01$ \\
\hline
\end{tabular}

${ }^{\mathrm{a}-\mathrm{d}}$ Means within a row with unlike superscripts differ $(P<0.05)$.

${ }^{1}$ Adapted from Vander Pol et al. (2006a).

${ }^{2} \mathrm{SFC}=$ steam-flaked corn, HMC = high-moisture corn, and DRC = dry rolled corn.

${ }^{3}$ Calculated from adjusted final BW.

${ }^{4}$ Calculated as total feed intake (DM basis) divided by total gain.

${ }^{5} 400=$ Slight $^{0}, 500=$ Small $^{0}$. diets consisting of DRC, HMC, or SFC $(3 \times 4$ factorial arrangement). Interactions for $\mathrm{ADG}$ and $\mathrm{G}: \mathrm{F}$ were observed between level of WDGS and grain processing type (Figure 1). At 0\% WDGS, the SFC had $14 \%$ greater feeding value than DRC, which is consistent with Cooper et al. (2002) and Owens et al. (1997). When WDGS was added to DRC, there was a linear increase $(P<$ 0.01) in G:F such that at $40 \%$ inclusion, the G:F was similar to that of the SFC diets. When WDGS was added to the SFC diets, there was no change in G:F. The feeding value for WDGS in SFC diets appears to be equal to SFC, which was $14 \%$ greater than DRC in this study. However, WDGS had 34\% greater feeding value than DRC averaged across levels in this study. The HMC diet with 0\% WDGS gave G:F values similar to the SFC diet without WDGS. However, addition of WDGS to HMC gave a linear $(P<0.05)$ increase in G:F. Whereas this experiment clearly showed the interaction between WDGS level and grain type on cattle performance, it certainly did not explain possible mechanisms. The relatively poor response to WDGS in SFC diets has also been shown by May et al. (2007b).

\section{GRAIN FERMENTED}

Whereas corn is the primary grain used for ethanol production, grain sorghum has been and continues to be used as a feedstock. The grains have similar amounts of starch and therefore have similar ethanol yields. Sorghum is usually less expensive than corn so it is an attractive feedstock for ethanol plants. Lodge et al. 
(1997a) suggested that sorghum DGS had less feeding value than corn DGS. However, their comparison was somewhat indirect because it compared feeding values across rather than within studies. Al-Suwaiegh et al. (2002) made a direct comparison of sorghum and corn DGS made from the same ethanol plant. The 2 DGS were fed at $30 \%$ of the diet with DRC. Although the G:F was not different, it favored corn DGS by $3 \%$, giving the corn $10 \%$ greater feeding value. Two additional experiments have been reported where sorghum DGS was compared with corn DGS. Levels of DGS fed were lower than those reported by Al-Suwaiegh et al. (2002), so the DGS was used primarily as a protein source. In addition, diets were based on SFC and the DGS were produced by different ethanol plants. Galyean and Vasconcelos (2007) reported statistically similar responses in G:F for sorghum and corn DGS (0.169 and 0.176, respectively), but the feeding value of the corn DGS was $40 \%$ greater than the sorghum DGS. Depenbusch et al. (2005) did not show a difference in G:F between sorghum and corn DGS ( 0.148 and 0.153 , respectively), but the feeding value of corn DGS was $25 \%$ greater than sorghum DGS. Considering the 4 experiments reported, one would conclude sorghum DGS was equal to corn DGS based on nonsignificant differences. However, the corn DGS was superior numerically to sorghum DGS in all experiments, causing us to conclude that it is risky to conclude the 2 are equivalent in feeding value.

Whereas little or no wheat is used for ethanol production in the United States, some is used in Western Canada because of availability relative to corn. The DGS resulting from fermentation of wheat has more $\mathrm{NDF}$ and less fat than that made from corn, whereas the protein is more degradable (Mustafa et al., 2000). Wheat DGS can be an effective source of protein and energy for growing and finishing cattle (Ojowi et al., 1997) and does not affect eating quality of the resulting product (Shand et al., 1998).

\section{Conclusions}

Distillers grains plus solubles is an excellent protein source for feedlot cattle, but as supplies increase, a greater amount is being used as energy sources replacing grain (primarily corn) that instead is being used as a feedstock by ethanol plants. The meta-analyses demonstrate that DGS has greater feeding value than DRC, the feeding value is dependent upon level of inclusion, and WDGS has greater feeding value than DDGS. Further, low quality roughage can be used with WDGS and the WDGS seems to add palatability and conditioning to the feedlot diet. Finally, there appears to be an interaction between level of DGS in the diet and type of grain processing applied. As with many aspects of ruminant nutrition, it is difficult to explain all of the interacting factors. This provides a great opportunity for researchers and practicing nutritionists to conduct research to explain the interacting factors.

\section{LITERATURE CITED}

Aines, G., T. Klopfenstein, and R. Stock. 1987. Distillers Grains. MP51, Nebraska Agric. Res. Div., Lincoln.

Al-Suwaiegh, S., K. C. Fanning, R. J. Grant, C. T. Milton, and T. J. Klopfenstein. 2002. Utilization of distillers grains from the fermentation of sorghum or corn in diets for finishing beef and lactating dairy cattle. J. Anim. Sci. 80:1105-1111.

Benson, C., K. Tjardes, and C. Wright. 2005. Effects of feeding varying concentrations of dry distillers grains with solubles to finishing steers on performance and odorant emissions. J. Anim. Sci. 83(Suppl. 1):247. (Abstr.)

Benton, J. R., G. E. Erickson, T. J. Klopfenstein, K. J. VanderPol, and M. A. Greenquist. 2007. Effects of roughage source and level in finishing diets containing wet distillers grains on feedlot performance. J. Anim. Sci. 85(Suppl. 2):76. (Abstr.)

Bremer, V. B., G. E. Erickson, T. J. Klopfenstein, M. L. Gibson, K. J. Vander Pol, and M. A. Greenquist. 2005. Feedlot performance of a new distillers byproduct (Dakota Bran) for finishing cattle. J. Anim. Sci. 83(Suppl. 1):125. (Abstr.)

Bruning, C. L., and M. T. Yokoyama. 1988. Characteristics of live and killed brewer's yeast slurries and intoxication by intraruminal administration to cattle. J. Anim. Sci. 66:585-591.

Buckner, C. D., G. E. Erickson, T. J. Klopfenstein, R. A. Stock, and K. J. Vander Pol. 2006. Effect of feeding a byproduct combination at two levels or byproduct alone in feedlot diets. J. Anim. Sci. 84(Suppl. 2):48. (Abstr.)

Buckner, C. D., T. L. Mader, G. E. Erickson, S. L. Colgan, K. K. Karges, and M. L. Gibson. 2007. Optimum levels of dry distillers grains with solubles for finishing beef steers. Nebraska Beef Cattle Report. MP90:36-38.

CAST. 2006. Convergence of agriculture and energy: Implications for research and policy. CAST Commentary: QTA 2006-3. http:// www.cast-science.org/websiteUploads/publicationPDFs/ QTA2006-3.pdf Accessed July 3, 2007.

Cooper, R. J., C. T. Milton, T. J. Klopfenstein, and D. J. Jordon. 2002. Effect of corn processing on degradable intake protein requirement of finishing cattle. J. Anim. Sci. 80:242-247.

Corrigan, M., G. Erickson, T. Klopfenstein, K. Vander Pol, M. Greenquist, and M. K. Luebbe. 2007. Effect of corn processing method and wet distillers grains inclusion level in finishing diets. J. Anim. Sci. 85(Suppl. 2):130.

DeHaan, K., T. Klopfenstein, and R. Stock. 1983. Corn gluten feedprotein and energy source for ruminants. Nebraska Beef Cattle Report MP44:19-21.

DeHaan, K. D., T. J. Klopfenstein, R. A. Stock, S. Abrams, and R. A. Britton. 1982. Wet distillers byproducts for growing ruminants. Nebraska Beef Cattle Report. MP43:33-35.

Depenbusch, B. E., J. S. Drouillard, E. R. Loe, and M. E. Corrigan. 2005. Optimizing use of distiller's grains in finishing cattle diets. J. Anim. Sci. 83(Suppl. 1):325. (Abstr.)

Drouillard, J., R. Daubert, E. Loe, B. Depenbusch, J. Sindt, M. Greenquist, and M. Corrigan. 2005. Wet sorghum distiller's grains with solubles in flaked corn finishing diets for heifers. J. Anim. Sci. 83(Suppl. 2):95. (Abstr.)

Farlin, S. D. 1981. Wet distillers grains for finishing cattle. Anim. Nutr. Health 36:35-36.

Farran, T. B., G. E. Erickson, T. J. Klopfenstein, C. N. Macken, and R. U. Lindquist. 2006. Wet corn gluten feed and alfalfa hay levels in dry-rolled corn finishing diets: Effects on finishing performance and feedlot nitrogen mass balance. J. Anim. Sci. 84:1205-1214.

Firkins, J. L., L. L. Berger, and G. C. Fahey Jr. 1985. Evaluation of wet and dry distillers grains and wet and dry corn gluten feeds for ruminants. J. Anim. Sci. 60:847-860.

Galyean, M. L., and J. T. Vasconcelos. 2007. University research updates: Texas Tech University Burnett Center. Proc. Plains Nutr. Counc. Spring Meet., San Antonio, TX. Texas A\&M Ext. Publ. No. AREC 07-20.

Garrigus, W. P., and E. S. Good. 1942. Distillery slop for beef cattle. Ky. Agric. Exp. Sta., Spec. Bull. 280. 
Ham, G. A., R. A. Stock, T. J. Klopfenstein, E. M. Larson, D. H. Shain, and R. P. Huffman. 1994. Wet corn distillers byproducts compared with dried corn distillers grains with solubles as a source of protein and energy for ruminant. J. Anim. Sci. 72:3246-3257.

Henry, W. A. 1900. Dried distillery grains compared with oats. Feeds and Feeding 2nd ed. 421. Morrison Publishing Co., Ithaca, NY.

Herold, D. W. 1999. Solvent extracted germ meal for ruminants. PhD Diss. University of Nebraska, Lincoln.

Huntington, G. B., and S. L. Archibeque. 2000. Practical aspects of urea and ammonia metabolism in ruminants. Proc. Am. Soc. Anim. Sci. 1999. http://www.asas.org/symposia/proceedings/filename Accessed Oct. 29, 2007.

Jenschke, B. E., J. M. James, K. J. Vander Pol, T. J. Klopfenstein, and C. R. Calkins. 2007. Wet distillers grains plus solubles do not increase liver-like off flavors in cooked beef from yearling steers. J. Muscle Foods 18:341-348.

Klopfenstein, T., J. Waller, N. Merchen, and L. Petersen. 1978. Distillers grains as a naturally protected protein for ruminants. Distillers Feed Conference Proceedings 33:38-46.

Krehbiel, C. R., R. A. Stock, D. W. Herold, D. H. Shain, G. A. Ham, and J. E. Carulla. 1995. Feeding wet corn gluten feed to reduce subacute acidosis in cattle. J. Anim. Sci. 73:2931-2939.

Larson, E. M., R. A. Stock, T. J. Klopfenstein, M. H. Sindt, and R. P. Huffman. 1993. Feeding value of wet distillers byproducts for finishing ruminants. J. Anim. Sci. 71:2228-2236.

Little, C. O., G. E. Mitchell Jr., and G. D. Potter. 1968. Nitrogen in the abomasums of weathers fed different protein sources. J. Anim. Sci. 27:1722-1726.

Lodge, S. L., R. A. Stock, T. J. Klopfenstein, D. H. Shain, and D. W. Herold. 1997a. Evaluation of corn and sorghum distillers byproducts. J. Anim. Sci. 75:37-43.

Lodge, S. L., R. A. Stock, T. J. Klopfenstein, D. H. Shain, and D. W. Herold. 1997b. Evaluation of wet distillers composite for finishing ruminants. J. Anim. Sci. 75:44-50.

Lonergan, G. H., J. J. Wagner, D. H. Gould, F. B. Garry, and M. A. Thoren. 2001. Effects of water sulfate concentration on performance, water intake, and carcass characteristics of feedlot steers. J. Anim. Sci. 79:2941-2948.

Luebbe, M. K., G. E. Erickson, T. J. Klopfenstein, and M. A. Greenquist. 2007. Effect of wet distillers grains level on feedlot cattle performance and nitrogen mass balance. J. Anim. Sci. 85(Suppl. 2):130. (Abstr.)

Macken, C. N., G. E. Erickson, T. J. Klopfenstein, and R. A. Stock. 2006. Effects of corn processing method and protein concentration in finishing diets containing wet corn gluten feed on cattle performance. Prof. Anim. Sci. 22:14-22.

May, M. L., M. L. Hands, M. J. Quinn, B. E. Depenbusch, J. O. Wallace, C. D. Reinhardt, and J. S. Drouillard. 2007a. Dry distiller's grains with solubles in steam-flaked or dry-rolled corn diets with reduced roughage levels. J. Anim. Sci. 85(Suppl. 1):411. (Abstr.)

May, M. L., M. J. Quinn, J. J. Higgins, and J. S. Drouillard. 2007b. Wet distiller's grains with solubles in beef finishing diets with steam-flaked or dry-rolled corn. Page 99 in Proc. Plains Nutr. Counc. Spring Conf., San Antonio, Texas. Texas A\&M Ext. Publ. No. AREC 07-20.

McDonald, I. W. 1954. The extent of conversion of feed protein to microbial protein in the rumen of sheep. Biochem. J. 56:120-125.

Morrison. 1939. Feeds and Feeding. 20th ed. Morrison Publishing Co., Ithaca, NY.

Mustafa, A. F., J. J. McKinnon, M. W. Ingledew, and D. A. Christensen. 2000. The nutritive value for ruminants of thin stillage and distillers' grains derived from wheat, rye, triticale and barley. J. Sci. Food Agric. 80:607-613.

Ojowi, M. O., J. J. McKinnon, A. F. Mustafa, and D. A. Christensen. 1997. Evaluation of wheat-based wet distillers grains for feedlot cattle. Can. J. Anim. Sci. 77:447-454.

Owens, F. N., D. S. Secrist, W. J. Hill, and D. R. Gill. 1997. The effect of grain source and grain processing on performance of feedlot cattle: A review. J. Anim. Sci. 75:868-878.

Plascencia, A., G. D. Mendoza, C. Vásquez, and R. A. Zinn. 2003. Relationship between body weight and level of fat supplementation on fatty acid digestion in feedlot cattle. J. Anim. Sci. 81:2653-2659.

Quicke, G. V., O. G. Bentley, H. W. Scott, R. R. Johnson, and A. L. Moxon. 1959. Digestibility of soybean hulls and flakes and the in vitro digestibility of the cellulose in various milling by-products. J. Dairy Sci. 42:185-186.

Roeber, D. L., R. K. Gill, and A. DiCostanzo. 2005. Meat quality responses to feeding distiller's grains to finishing Holstein steers. J. Anim. Sci. 83:2455-2460.

Sayer, K. M. 2004. Effects of corn bran and steep inclusion in finishing diets on cattle performance, nutrient mass balance, and diet digestibility. MS Thesis University of Nebraska, Lincoln.

Shain, D. H., R. A. Stock, T. J. Klopfenstein, and D. W. Herold. 1999. The effect of forage source and particle size on finishing yearling steer performance and ruminal metabolism. J. Anim. Sci. 77:1082-1092.

Shand, P. J., J. J. McKinnon, and D. A. Christensen. 1998. Eating quality of beef from animals fed wet brewers grains and wheatbased wet distillers' grains. Can. J. Anim. Sci. 78:143-146.

Stock, R. A., J. M. Lewis, T. J. Klopfenstein, and C. T. Milton. 2000. Review of new information on the use of wet and dry milling feed by-products in feedlot diets. J. Anim. Sci. 78(E-Suppl.). http://www.asas.org/symposia/9899proc/0924.pdf Accessed July 3, 2007.

Trenkle, A. H. 1996. Evaluation of wet distillers grains for finishing cattle. Beef Res. Rep., Iowa State Univ., Ames. AS632:75-80.

Trenkle, A. 1997. Evaluation of wet distillers grains in finishing diets for yearling steers. Beef Research Rep. Iowa State Univ., Ames. AS637:93-96.

Vander Pol, K. J., G. E. Erickson, M. A. Greenquist, T. J. Klopfenstein, and T. Robb. 2006a. Effect of corn processing in finishing diets containing wet distillers grains on feedlot performance and carcass characteristics of finishing steers. Nebraska Beef Cattle Report. MP84:48-50.

Vander Pol, K. J., G. E. Erickson, T. J. Klopfenstein, M. A. Greenquist, and T. Robb. 2006b. Effect of dietary inclusion of wet distillers grains on feedlot performance of finishing catle and energy value relative to corn. Nebraska Beef Cattle Report. MP88-A:51-53.

Vander Pol, K. J., M. K. Luebbe, G. I. Crawford, G. E. Erickson, and T. J. Klopfenstein. 2007. Digestibility, rumen metabolism and site of digestion for finishing diets containing wet distillers grains or corn oil. Nebraska Beef Cattle Report. MP90:39-42.

Vasconcelos, J. T., and M. L. Galyean. 2007. Nutritional recommendations of feedlot consulting nutritionists: The 2007 Texas Tech University survey. J. Anim. Sci. 85:2772-2781.

Zinn, R. A. 1989. Influence of level and source of dietary fat on its comparative feeding value in finishing diets for steers: Feedlot cattle growth and performance. J. Anim. Sci. 67:1029-1037.

Zinn, R. A., S. K. Gulai, A. Plascencia, and J. Salinas. 2000. Influence of ruminal biohydrogenation on the feeding value of fat in finishing diets for feedlot cattle. J. Anim. Sci. 78:1738-1746. 